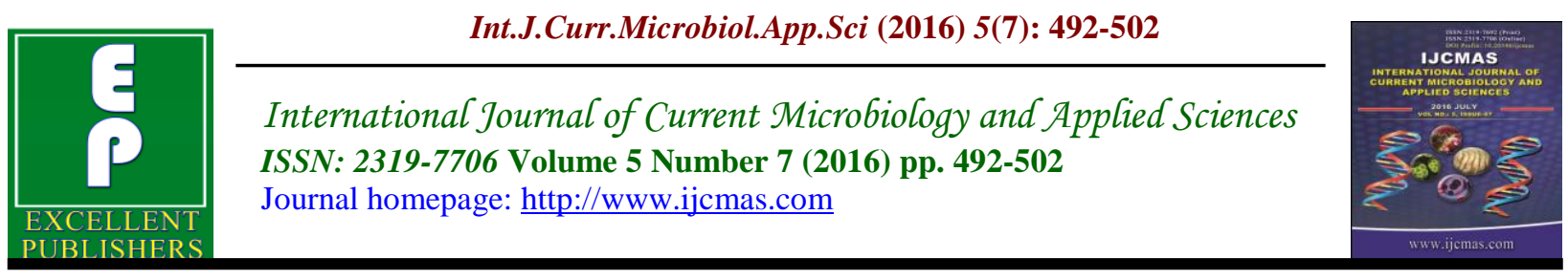

Original Research Article

http://dx.doi.org/10.20546/ijcmas.2016.507.054

\title{
$\beta$-Galactosidase from Enterobacter cloacae: Production, Characterization and Purification
}

\author{
Anamika Ghatak* \\ Department of Microbiology, Tara Devi Harakhchand Kankaria Jain College, \\ Cossipore, Kolkata - 700002, India \\ *Corresponding author
}

\begin{tabular}{|c|c|}
\hline & A B S T R A C T \\
\hline \multicolumn{2}{|l|}{ Keywords } \\
\hline $\begin{array}{l}\text { Enterobacter } \\
\text { cloacae, } \\
\text { intracellular } \\
\text { enzyme, } \\
\text { ultrasonication, } \\
\text { purification, } \\
\text { characterization. }\end{array}$ & \multirow{4}{*}{$\begin{array}{l}\text { The objective of the present study was to characterize an intracellular } \beta \text { - } \\
\text { galactosidase from Enterobacter cloacae St. SJ } 6 \text {. The yield of the enzyme } \\
\text { obtained by disrupting the cells using ultrasonication is found to be better } \\
\text { compared with other methods. Maximum production of the enzyme is noted in the } \\
\text { medium composed of }(\mathrm{g} / \mathrm{L}) \text { : Lactose, } 15 ; \mathrm{KH}_{2} \mathrm{PO}_{4}, 1 ; \mathrm{KCl}, 0.5 ; \mathrm{NaNO}_{3}, 2 ; \mathrm{MgSO}_{4} \text {, } \\
7 \mathrm{H}_{2} \mathrm{O}, 0.5 ; \mathrm{FeSO} \mathrm{SO}_{4}, 7 \mathrm{H} \mathrm{O}, 0.01 \text {; Malt extract, } 1 ; \mathrm{Yeast} \text { extract, } 1 ; \mathrm{Agar}_{2} \% \text {, } \mathrm{pH} \\
7.0 \pm 0.2 ; \text { using } 1.5 \% \text { cell suspension on } 72 \mathrm{~h} \text { cell growth at } 30^{\circ} \mathrm{C} \text {.Tryptone } \\
\text { enhanced the production enzyme. The obtained } \mathrm{K}_{\mathrm{m}} \text { and } \mathrm{V}_{\max } \text { values were } 7.92 \mathrm{mM} \\
\text { and } 134.3 \mu \mathrm{Mole} / \mathrm{min} / \mathrm{mg} \text {, respectively. The enzyme has been purified } 12.48 \text { fold by } \\
\text { Sephadex G- } 100 \text { chromatography. The optimum } \mathrm{pH} \text { and temperature for maximum } \\
\text { activity of the purified enzyme are found to be } 9.0 \text { and } 50^{\circ} \mathrm{C} \text {, respectively. } \mathrm{Ca}^{2+} \text {, } \\
\mathrm{Co}^{2+} \text {, mercaptoethanol, polyethyleneglycol, sodium azide and CTAB stimulated the } \\
\text { activity of the enzyme. }\end{array}$} \\
\hline Ar & \\
\hline $\begin{array}{l}\text { epted: } \\
\text { June } 2016\end{array}$ & \\
\hline $\begin{array}{l}\text { Available Online: } \\
\text { 10 July } 2016\end{array}$ & \\
\hline
\end{tabular}

\section{Introduction}

$\beta$-D-Galactosidase or lactase is one of the most industrially important enzymes and finds widespread application in pharmaceutical, food and dairy industries. A large portion of global population cannot digest lactose, which is the main carbohydrate constituent of milk due to the presence of insufficient amount of this lactase in the intestine causing health problems (Shukla, 1975). In ice cream and condensed milk industries, high amount of lactose also causes crystallization problem. The presence of high amount of lactose in whey causes environmental pollution due to its high biochemical oxygen demand (BOD) (Becerra et al., 2001; Gonzalez-Siso, 1996). High BOD value of whey must be reduced to permissible limit before discharging into sewage system. One of the possibilities of reducing the BOD value is to produce some valuable products such as baker's yeast, alcohols etc. from whey which requires hydrolysis of lactose. All these create high demand of $\beta$ galactosidase in industry (Giacomini et al., 1998; Husain, 2010).

$\beta$-Galactosidase can be obtained from a variety of sources such as microorganisms, 
plants and animals but their properties differ depending on the sources (Chakraborti et al., 2003;. Panesar et al., 2006) Different methods are available for disintegration of microorganism to isolate intracellular enzymes and their purification as relatively pure enzymes will be needed for a number of the applications (Fonseca et al.,2002; Ganeva et al., 2001; Kula et al., 1987; Nagy et al., 2001).

This paper describes certain parameters required for the production of crude enzyme along with nutritional requirements of the selected strain followed by purification of the enzyme and determination of some physicochemical properties of the purified enzyme.

\section{Materials and Methods}

\section{Chemicals and reagents}

All chemicals used in the present study were purchased from E.Merck, Germany. Ingredients of microbiological media were procured from Himedia, India. DEAE Sepharose and Sephadex chromatography columns were obtained by Sigma Aldrich.

\section{Microorganism and medium}

Enterobacter cloacae St SJ 6, isolated from soil and identified in our laboratory (Ghatak et al., 2010) was used for the present study. The organism was maintained in the medium composed of $(\mathrm{g} / \mathrm{L})$ : Lactose, 15; $\mathrm{KH}_{2} \mathrm{PO}_{4}, 1 ; \mathrm{KCl}, 0.5 ; \mathrm{NaNO}_{3}, 2 ; \mathrm{MgSO}_{4}$, $7 \mathrm{H}_{2} \mathrm{O}, 0.5 ; \mathrm{FeSO}_{4}, 7 \mathrm{H}_{2} \mathrm{O}, 0.01$; Malt extract, 1; Yeast extract, 1; Agar 20 , pH 7.0 0.2 , by monthly sub culturing at $30^{\circ} \mathrm{C}$ for $24-48 \mathrm{~h}$ and stored at $4^{\circ} \mathrm{C}$.

\section{Production of $\beta$-Galactosidase enzyme}

Inoculum and fermentation medium was composed of the above mentioned ingredients except agar. Inoculum was prepared by transferring a loopful culture of E. cloacae from agar slant to $20 \mathrm{ml}$ inoculum medium in $100 \mathrm{ml}$ Erlenmeyer flask and incubated for $24 \mathrm{~h}$ at $30^{\circ} \mathrm{C}$ with shaking (120 r.p.m). $1 \mathrm{ml}$ of the inoculum was added to $50 \mathrm{ml}$ fermentation medium in $250 \mathrm{ml}$ Erlenmeyer flask and incubated for $72 \mathrm{~h}$, other conditions remaining the same. The cells were harvested by centrifugation at 5000 r.p.m, for $20 \mathrm{~min}$ at $4^{\circ} \mathrm{C}$, washed twice with phosphate buffer ( $\mathrm{pH}$ 7.0) and used for intracellular enzyme isolation.

\section{Intracellular enzyme extraction}

Different chemical and physical methods were employed to disrupt E. cloacae cells to isolate the intracellular enzyme; all operations were carried out at chilled conditions.

Treatment with Solvent and Grinding with abrasives (Numanoglu et al., 2004): Hervested cells $(1.1 \pm 0.41 \mathrm{gm}$ wet cell $/ 50 \mathrm{ml})$ of $E$. cloacae were grinded with $10 \mathrm{~g}$ powdered alumina and $0.1 \mathrm{ml}$ ice-cold toluene-acetone mixture $(9: 1)$ in a morterpestle with gradual addition of $10 \mathrm{ml}$ phosphate buffer followed by centrifugation at $4^{\circ} \mathrm{C}(5,000$ r.p.m, $10 \mathrm{~min})$ and the clear supernatant was used for enzyme assay.

Treatment with detergent and solvent (Numanoglu et al., 2004; Bansal et al., 2008): Hervested E. cloacae cells (1.2 \pm $0.29 \mathrm{gm}$ cells / $50 \mathrm{ml}$ ) were treated with $0.01 \%$ SDS and $200 \mu \mathrm{l}$ chloroform using chilled $\mathrm{Z}$ buffer $\left(\mathrm{Na}_{2} \mathrm{HPO}_{4}, 7 \mathrm{H}_{2} \mathrm{O}, 0.8 \mathrm{~g}\right.$; $\mathrm{NaH}_{2} \mathrm{PO}_{4}, \mathrm{H}_{2} \mathrm{O}, 0.28 \mathrm{~g} ; 1 \mathrm{M} \mathrm{KCl}, 0.05 \mathrm{ml}$; $1 \mathrm{M} \mathrm{MgSO}_{4}, 0.05 \mathrm{ml} ; \beta$-mercaptoethanol, $0.135 \mathrm{ml}$, per $50 \mathrm{ml}$, pH 7.0) . The suspension was centrifuged at $4^{\circ} \mathrm{C}, 5,000$ r.p.m for $10 \mathrm{~min} \&$ the clear supernatant was used for enzyme assay.

Treatment with detergent and abrasives: 1 $\mathrm{ml}$ of $1 \%$ CTAB was added to $50 \mathrm{ml}$ cell 
suspension contains $1.25 \pm 0.24 \mathrm{gm}$ wet cell/ $50 \mathrm{ml}$ and incubated for $3 \mathrm{~h}$ at $30^{\circ} \mathrm{C}$ with mild shaking, then it was centrifuged and the cell pellet was grinded using sea- sand with gradual addition of phosphate buffer $(\mathrm{pH}$ 7.0). This was centrifuged and the supernatant was assayed.

Use of abrasives (Bansal et al., 2008): $1.19 \pm 0.36 \mathrm{gm}$ wet cell of $E$. cloacae in 50 $\mathrm{ml}$ was suspended in $10 \mathrm{ml}$ phosphate buffer $(\mathrm{pH}$ 7.0) and disrupted by adding equal volume of glass beads and stirring vigorously in a vortex. Cell debris along with glass beads were removed by centrifugation and the supernatant was used for enzyme assay.

Utrasonication (Becerra et al., 2001; Georis et al.,2000;): Harvested E. cloacae cells $(1.2 \pm 0.28 \mathrm{gm}$ wet cell) suspended in $50 \mathrm{ml}$ phosphate buffer ( $\mathrm{pH}$ 7.0) were sonicated for $30 \mathrm{~min}$ in a Takashi Ultrasonicator (Takashi Electric Co. Limited, Tokyo, Japan) under chilled condition $\left(4^{\circ} \mathrm{C}\right)$ with an interval of $5 \mathrm{~min}$. This was centrifuged at $4^{\circ} \mathrm{C}(10,000 \mathrm{rpm})$ for $15 \mathrm{~min}$. The clear supernatant was used for intracellular $\beta$ galactosidase assay.

\section{Enzyme assay}

Immediately after cell disintegration, the activity of intracellular $\beta$-Galactosidase was determined using a substrate orthonitrophenyl- $\quad \beta$-D-galactopyranoside (ONPG) as described by a method of Onishi and coauthor (Onishi et al., 1995). 1 unit of enzyme activity is defined as the amount of enzyme required to produce $1 \mu$ mole of orthonitrophenol (ONP) per min under standard assay conditions. Each experiment was performed in triplicate. Protein was estimated following the method described by Lowry using bovine serum albumin as the standard (Lowry et al., 1951).

\section{Effect of carbon and nitrogen sources on enzyme production}

To the basal medium used for $\beta$ galactosidase production, a given carbon compound is added in $1.5 \%$ concentration. 13 different carbohydrates other than lactose were tested. Different organic nitrogen $\left(\mathrm{N}_{2}\right.$ level $0.165 \mathrm{gm}$ per lit) and inorganic nitrogen $\left(\mathrm{N}_{2}\right.$ level $\left.33 \mathrm{mg} / 100 \mathrm{ml}\right)$ sources were also determined by adding them separately to the basal medium. All flasks containing media were autoclaved accordingly.

\section{Determination of $\mathbf{V}_{\max }$ and $K_{m}$}

$\mathrm{V}_{\max }$ and $\mathrm{K}_{\mathrm{m}}$ values for $\beta$-galactosidase were determined using the Lineweaver-Burk plot. This investigation was carried out by using ONPG in the concentration range: $1.25,2.5$, 4.0, 5.0, $6.0 \mathrm{mM}$.

\section{Purification of enzyme}

Enterobacter cloacae intracellular $\beta$ galactosidase was purified from the culture filtrate by ammonium sulphate precipitation followed by dialysis. Saturation from 20 $80 \%$ was achieved for proteins to precipitate. Each precipitate was collected by centrifugation. The fractions showing maximum activity were dissolved in minimum amount of $0.2 \mathrm{M}$ Glycine- $\mathrm{NaOH}$ buffer $(\mathrm{pH}$ 9.0) and dialyzed against the same buffer overnight using a magnetic stirrer and changing the buffer solution twice during the dialysis.

The dialyzed protein was collected by centrifugation. Purification was further achieved by gel filtration chromatography on a DEAE- Sepharose FF column $(25 \times 2 \mathrm{~cm}$, Sigma -Aldrich) equilibrated with $0.25 \mathrm{M}$ $\mathrm{NaCl} / 0.05 \mathrm{M}$ sodium phosphate buffer $(\mathrm{pH}$ 7.0). Fractions of $2.0 \mathrm{ml}$ were collected at a flow rate $0.5 \mathrm{ml} / \mathrm{min}$ using a fraction 
collector. $\beta$-galactosidase activity and protein content were determined for collected fractions. The active fractions were combined and further purified by Sephadex G-100 (20X1 cm) columns. Elution was performed by applying a linear salt gradient $(0 \sim 0.5 \mathrm{M} \mathrm{NaCl}$ n $50 \mathrm{mM}$ sodium phosphate buffer ( $\mathrm{pH}$ 7.0). Fractions $(2.0 \mathrm{ml}$ each) were again collected at a flow rate 0.5 $\mathrm{ml} / \mathrm{min}$ and analyzed for protein concentration and $\beta$-galactosidase activity.

\section{Polyacrylamide Gel Electrophoresis}

To determine the purity and the molecular weight of $\beta$-galactosidase, SDS- PAGE was carried out following the method of Laemmli (1970). After electrophoresis, gels were stained with $0.25 \%$ Coomassie Brilliant Blue R-250. Enzyme molecular weight was estimated by comparing the mobility of the enzyme with those of standard proteins. Thyroglobulin $(669 \mathrm{kDa})$, Ferritin (440 kDa), Catalase (232 kDa), Lactate dehydrogenase $(140 \mathrm{kDa})$ were included as molecular weight markers.

\section{Determination of reaction $\mathrm{pH}$ and $\mathrm{pH}$ stability of the purified enzyme}

The enzyme-substrate reaction was carried out at different $\mathrm{pH}$ ranges viz. 6.0- 7.5, 7.58.5, 8.0-9.5 using 0.2 M Phosphate, $0.2 \mathrm{M}$ Tris-HCL and $0.2 \mathrm{M}$ glycine $-\mathrm{NaOH}$ buffers respectively at $50{ }^{\circ} \mathrm{C}$ for $5 \mathrm{~min}$. The $\mathrm{pH}$ stability of the purified enzyme was determined by incubating the enzyme with 4 $\mathrm{ml}$ of $0.2 \mathrm{M}$ glycine- $\mathrm{NaOH}$ buffer of $\mathrm{pH}$ (8.0-9.5) for $1 \mathrm{~h}$ and then preservation stability was determined by the standard assay method.

\section{Determination of reaction temperature and temperature stability}

The enzyme-substrate reaction was carried out at various temperatures viz. $30,35,40,45,50,55,60^{\circ} \mathrm{C}$ with partially purified $\beta$-galactosidase in $0.2 \mathrm{M}$ glycine$\mathrm{NaOH}$ buffer ( $\mathrm{pH} 9.0$ ) for 5 min with ONPG as substrate. The purified enzyme was incubated at different temperatures (20-60 ${ }^{\circ} \mathrm{C}$ ) for $1 \mathrm{~h}$ at $\mathrm{pH} 9.0$ using the same buffer. The residual activities were evaluated according to standard assay procedure.

\section{Effect of metal ions and reducing agents}

To investigate the effect of metal ions on the activity of purified $\beta$-galactosidase, each metal salt (as chloride or sulfate) was added to the reaction mixture at $0.5,1.0,5.0$ and 10 $\mathrm{mM}$ final concentration. Similarly, reducing agents such as mercaptoethanol, polyethyleneglycol, sodium azide and CTAB were tested at 1.0, 5.0 and $10 \mathrm{mM}$ final concentrations. Activity was measured using standard assay method.

\section{Results and discussion}

\section{Cell disruption}

Different methods have been employed to release intracellular enzymes. Among them, cell disruption with sonication showed the best result with specific activity $14.03 \pm 2.04 \mathrm{IU} / \mathrm{mg}$ (Table 1). In the present study, the enzyme $\beta$-galactosidase from E.cloacae is found to be intracellular. Isolation of enzyme requires cell disintegration. The shock waves of sonicator disrupt cells present in suspension.

\section{Effect of superior carbon and nitrogen sources for fermentative production of $\beta$ - galactosidas}

Enzyme production depends on the composition of the growth medium which is not necessesarily the same that supports the best growth. Carbon source of the medium greatly influences $\beta$-galactosidase 
production (Hsu et al., 2005). A number of carbon sources at a concentration of $1.5 \%$ (other than lactose) were used in the fermentation medium keeping other parameters same.

Lactose $(1.5 \%)$ was found to be the superior carbon source for $\beta$-galactosidase production from Enterobacter cloacae (Fig.3). Different organic $\left(\mathrm{N}_{2}\right.$ level $0.165 \mathrm{gm}$ per lit) and inorganic $\left(\mathrm{N}_{2}\right.$ level 33 $\mathrm{mg} / 100 \mathrm{ml}$ ) nitrogen sources were tested (Elhofi et al., 2010). Sodium nitrate at $0.2 \%$ concentration was found to be the best inorganic nitrogen source having specific activity $14.07 \pm 1.76 \quad \mathrm{IU} / \mathrm{mg}$. Enzyme production was found to be high in presence of some amino acids viz. glycine \& glutamic acid $(0.495 \mathrm{gm}$ nitrogen/L) (Table 2). Amino acids used in production medium can often be used as growth enhancer.

\section{Determination of $V_{\text {max }}$ and $K_{m}$}

$V_{\max }$ and $K_{m}$ values for $\beta$-galactosidase were determined using the Lineweaver-Burk plot. $K_{m}$ and $V_{\text {max }}$ for enzyme substrate reaction were $7.92 \mathrm{mM}$ and $134.3 \mu \mathrm{mole} / \mathrm{min} / \mathrm{mg}$ respectively (Fig.2).

\section{Purification of $\beta$-Galactosidase}

The enzyme was purified 12.48 fold with $15.78 \%$ recovery. Purification process increased the specific activity from 12.24 to $152.83 \mathrm{IU} / \mathrm{mg}$ (Table 3). One prominent band having molecular weight $340 \mathrm{kDa}$ was appeared (Fig.3).

\section{Characteristics of purified enzyme}

\section{Effect of pH}

The enzyme-substrate reaction was carried out at different $\mathrm{pH}$ ranges viz. 6.0- 7.5, 7.58.5, 8.0-9.5 using three different buffers at $50^{\circ} \mathrm{C}$ for $5 \mathrm{~min}$ for each $\mathrm{pH}$. The $\mathrm{pH}$ stability of the partially purified enzyme was also determined by a method described above. The optimum $\mathrm{pH}$ for maximum enzyme activity was found to be 9.0 and the enzyme was stable at $\mathrm{pH}$ range 8.0-9.0(Fig. 4). $50.06 \%$ of activity was retained at $\mathrm{pH}$ 9.5. Fernandes et al. described the properties of a psychrotrophic $\beta$-galactosidase from Pseudoalteromonas sp. having an optimum activity at pH 9.0 (Fernandes et al., 2002)

Table.1 Extraction of $\beta$-galactosidase by different chemical and physical methods

\begin{tabular}{|l|c|c|}
\hline \multicolumn{1}{|c|}{ Methods } & Activity (IU/ml) & $\begin{array}{c}\text { Specific } \\
\text { activity(IU/mg) }\end{array}$ \\
\hline $\begin{array}{l}\text { Use of Abrasives } \\
\text { a) Glass beads } \\
\text { b) Sea sand }\end{array}$ & $20.8 \pm 1.5$ & $4.58 \pm 0.22$ \\
\hline Ultrasonication & $39 \pm 1.67$ & $11.2 \pm 0.46$ \\
\hline $\begin{array}{l}\text { Treatment with Solvent and grinding with } \\
\text { abrasive Toluene - Acetone- Alumina }\end{array}$ & $48 \pm 2.014$ & $14.03 \pm 2.04$ \\
\hline $\begin{array}{l}\text { Treatment with Detergent \& solvent } \\
\text { SDS-Chloroform-Mercaptoethanol }\end{array}$ & $26.5 \pm 0.2$ & $8.24 \pm 0.53$ \\
\hline Detergent treatment CTAB & $25.73 \pm 0.61$ & $10.65 \pm 0.71$ \\
\hline
\end{tabular}


Table.2 Effect of nitrogen sources on crude $\beta$-galactosidase production

\begin{tabular}{|c|c|c|c|}
\hline Nitrogen sources & $\begin{array}{c}\text { Growth (abs at } \\
600 \mathrm{~nm})\end{array}$ & Activity (IU/ml) & $\begin{array}{c}\text { Specific activity } \\
\text { (IU/mg) }\end{array}$ \\
\hline \multirow{9}{*}{$\begin{array}{l}\text { Control } \\
\text { Organic } \\
\text { Yeast extract } \\
\text { Malt extract } \\
\text { Tryptone } \\
\text { Peptone } \\
\text { Beef Extract } \\
\text { Casein } \\
\text { Hydrolysate* }\end{array}$} & 2.3 & $46.55 \pm 1.13$ & $14.07 \pm 1.76$ \\
\hline & & & \\
\hline & 1.9 & $49.55 \pm 0.07$ & $12.25 \pm 0.89$ \\
\hline & 1.9 & $40.0 \pm 1.33$ & $10.06 \pm 0.548$ \\
\hline & 2.8 & $84.26 \pm 1.708$ & $7.82 \pm 1.7$ \\
\hline & 1.8 & $41.1 \pm 3.38$ & $7.35 \pm 2.294$ \\
\hline & 1.5 & $10.5 \pm 1.087$ & $1.21 \pm 2.01$ \\
\hline & 2.5 & $81.5 \pm 2.16$ & $7.86 \pm 0.385$ \\
\hline & & & \\
\hline \multirow{7}{*}{$\begin{array}{c}\text { Inorganic } \\
\left(\mathrm{NH}_{4}\right) \mathrm{H}_{2} \mathrm{PO}_{4} \\
\left(\mathrm{NH}_{4}\right)_{2} \mathrm{HPO}_{4} \\
\left(\mathrm{NH}_{4}\right) \mathrm{Cl} \\
\left(\mathrm{NH}_{4}\right) \mathrm{NO}_{3} \\
\left(\mathrm{NH}_{4}\right)_{2} \mathrm{SO}_{4} \\
\text { Amino acids }\end{array}$} & & & \\
\hline & 1.4 & $28.14 \pm 1.13$ & $5.78 \pm 1.25$ \\
\hline & 1.2 & $17.76 \pm 0.62$ & $1.75 \pm 0.845$ \\
\hline & 0.9 & $10.52 \pm 1.06$ & $2.04 \pm 0.91$ \\
\hline & 1.5 & $9.70 \pm 0.33$ & $3.14 \pm 1.41$ \\
\hline & 1.1 & $10.525 \pm 2.081$ & $6.21 \pm 1.632$ \\
\hline & & & \\
\hline Glycine & 2.8 & $72.49 \pm 0.58$ & $19.97 \pm 1.4$ \\
\hline Glutamic acid & 2.3 & $68.33 \pm 1.32$ & $16.66 \pm 0.083$ \\
\hline
\end{tabular}

*Interference with assay procedure

Table.3 Purification of $\beta$-galactosidase

\begin{tabular}{|l|c|c|l|l|c|}
\hline $\begin{array}{l}\text { Stage of } \\
\text { purification }\end{array}$ & $\begin{array}{c}\text { Total } \\
\text { Protein(mg) }\end{array}$ & $\begin{array}{c}\text { Total } \\
\text { activity } \\
\text { (IU) }\end{array}$ & Recovery (\%) & $\begin{array}{c}\text { Specific } \\
\text { activity } \\
\text { (IU/mg) }\end{array}$ & $\begin{array}{c}\text { Purification } \\
\text { (fold) }\end{array}$ \\
\hline Crude extract & 114.65 & 1403.7 & 100 & 12.243 & 1 \\
\hline $\begin{array}{l}\text { Ammonium } \\
\text { sulfate (40\%) } \\
\text { and Dialysis }\end{array}$ & 9.63 & 968.1 & 68.96 & 100.53 & 8.213 \\
\hline $\begin{array}{l}\text { DEAE- } \\
\text { Sepharose }\end{array}$ & 2.30 & 344.83 & 24.56 & 149.92 & 12.24 \\
\hline Sephadex G-100 & 1.45 & 221.6 & 15.78 & 152.83 & 12.48 \\
\hline
\end{tabular}


Table.4 Effect of metal ions and reducing agents on purified enzyme

\begin{tabular}{|c|c|c|c|c|}
\hline \multirow{2}{*}{$\begin{array}{c}\text { Metal ions/Reducing } \\
\text { agents }\end{array}$} & \multicolumn{4}{|c|}{ Relative activity (\%) at concentrations (mM) } \\
\cline { 2 - 5 } & $\mathbf{0 . 5}$ & $\mathbf{1 . 0}$ & $\mathbf{5}$ & $\mathbf{1 0}$ \\
\hline $\mathbf{C a}^{2+}$ & 103.9 & 81.3 & 55.6 & 30.03 \\
$\mathbf{C o}^{2+}$ & 101.5 & 77.86 & 52.37 & 31.42 \\
$\mathbf{M g}^{\mathbf{2 +}}$ & 81.6 & 90.88 & 59.7 & 29.85 \\
$\mathbf{M n}^{2+}$ & 73.3 & 65.9 & 63.2 & 54.2 \\
$\mathbf{S n}^{2+}$ & 24.9 & 21.4 & 18.53 & 16.6 \\
$\mathbf{K}^{+}$ & 35.46 & 37.62 & 29.38 & 26.35 \\
$\mathbf{Z n}^{2+}$ & 26.97 & 29.8 & 23.13 & 21.2 \\
EDTA & & 47.04 & 92.7 & 36.42 \\
SDS & & 91.89 & 102.6 & 89.7 \\
Sodium azide & & 104 & 103.4 & 101.36 \\
Mercaptoethanol & & 109.9 & 88.0 & 71.3 \\
Polyetheleneglycol & & 105.1 & 63.1 & 62.43 \\
CTAB & & 79.96 & 106.2 & 61.83 \\
& & & & \\
\hline
\end{tabular}

Fig.1 Effect of different carbon sources on production of crude $\beta$-galactosidase

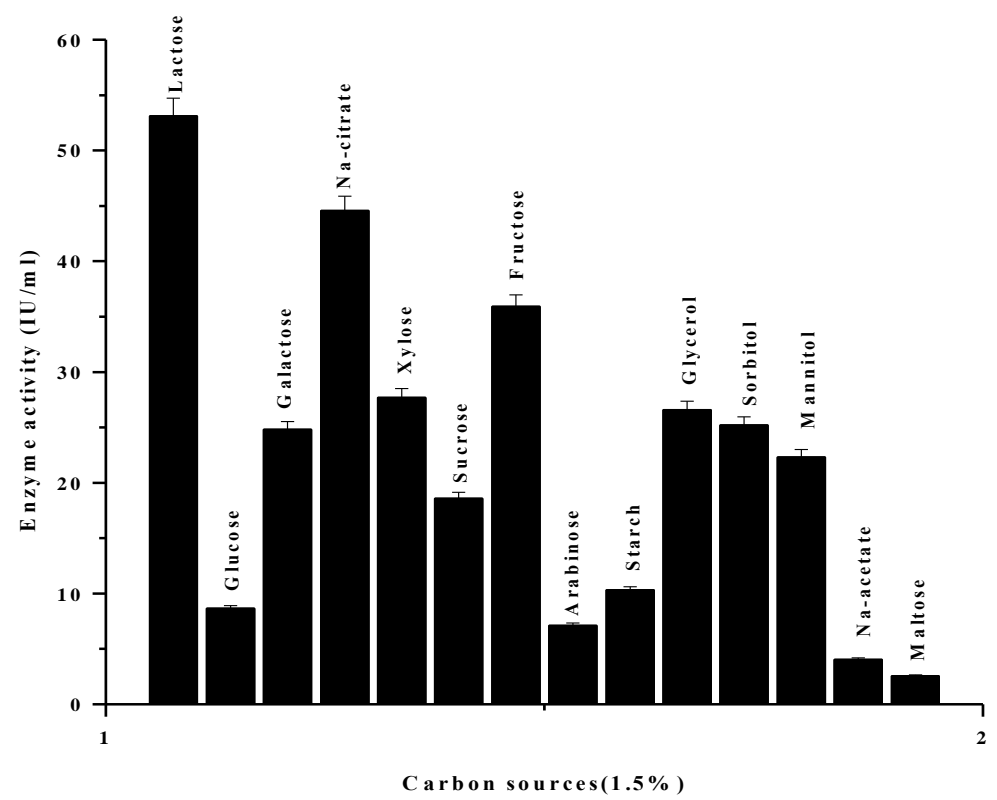


Fig.2 Line Weaver-Burk plot of $\beta$-galactosidase

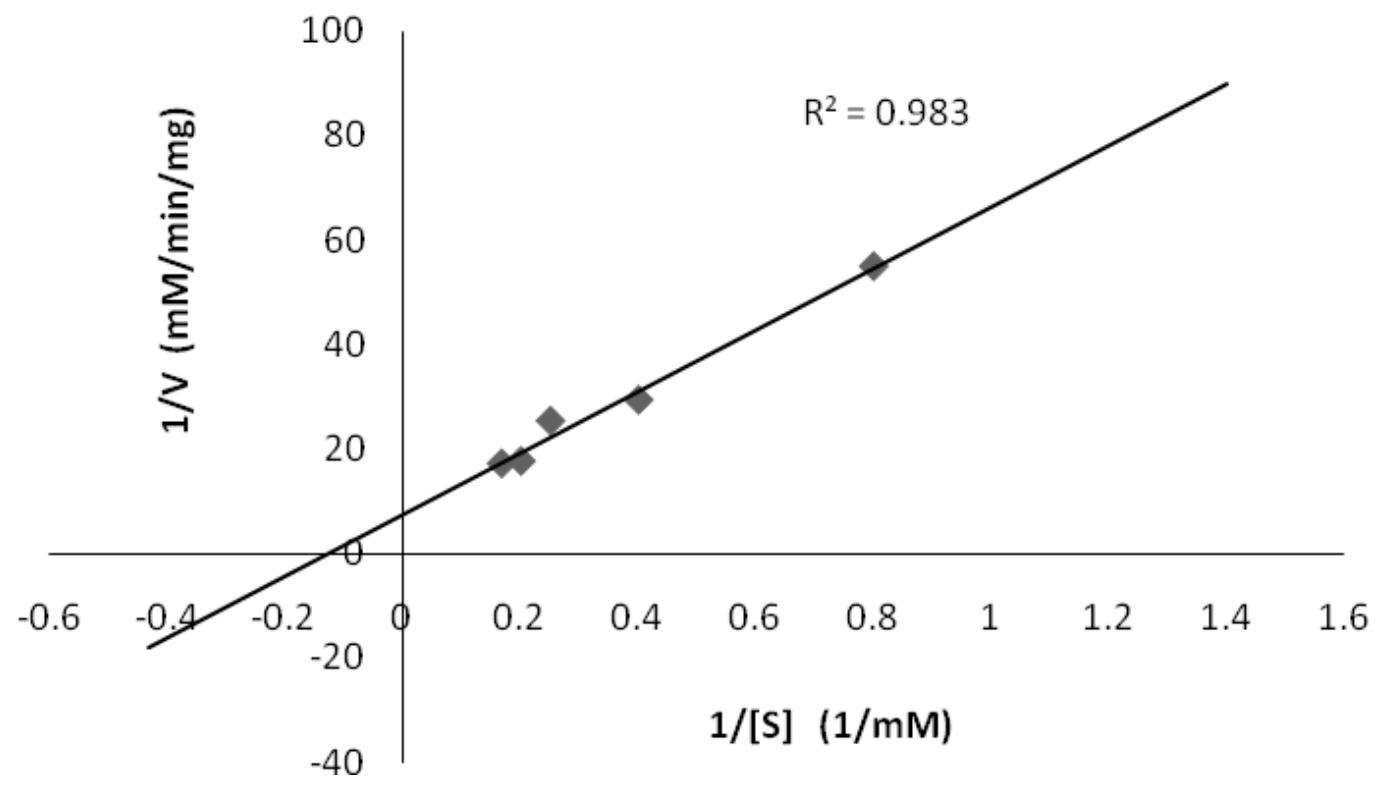

Fig.3 Polyacrylamide GEL electrophoresis pattern of Enterobacter cloacae $\beta$-galactosidase

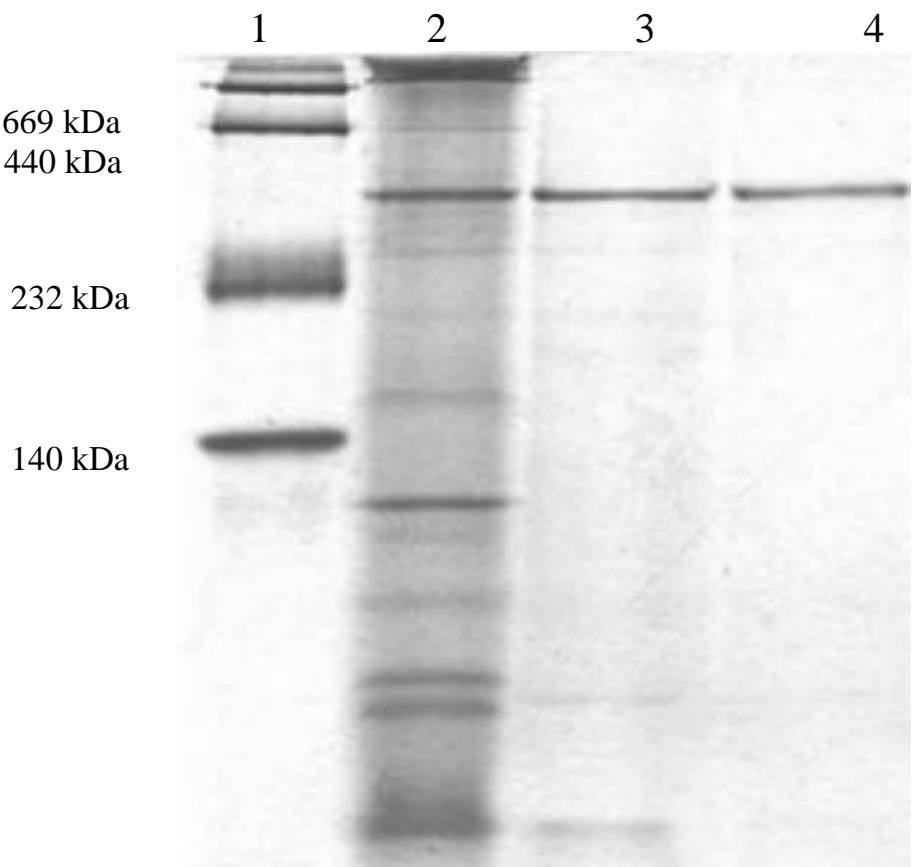

Lane 1: Markers; Lane 2: Dialyzed enzyme; Lane 3: DEAE-Sepharose; Lane 4: Sephadex G-100 
Fig.4 Effect of reaction $\mathrm{pH}$ and storage $\mathrm{pH}$ on purified enzyme activity

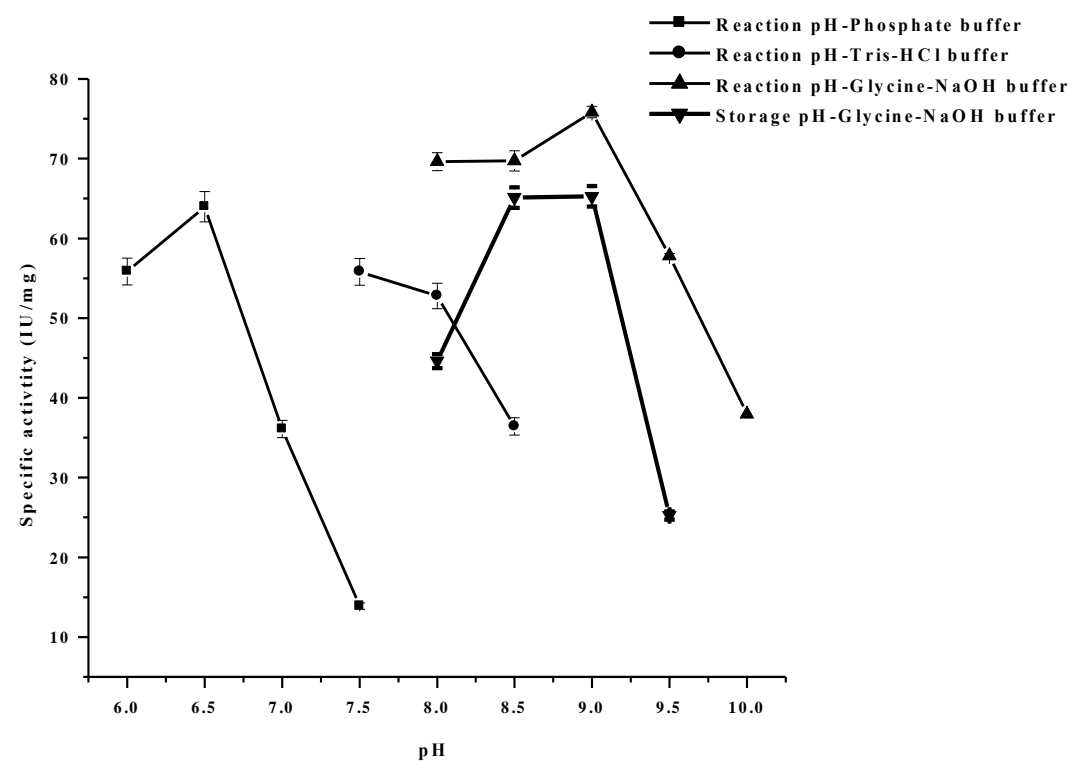

Fig.5 Effect of reaction temperature and storage temperature on purified enzyme activity

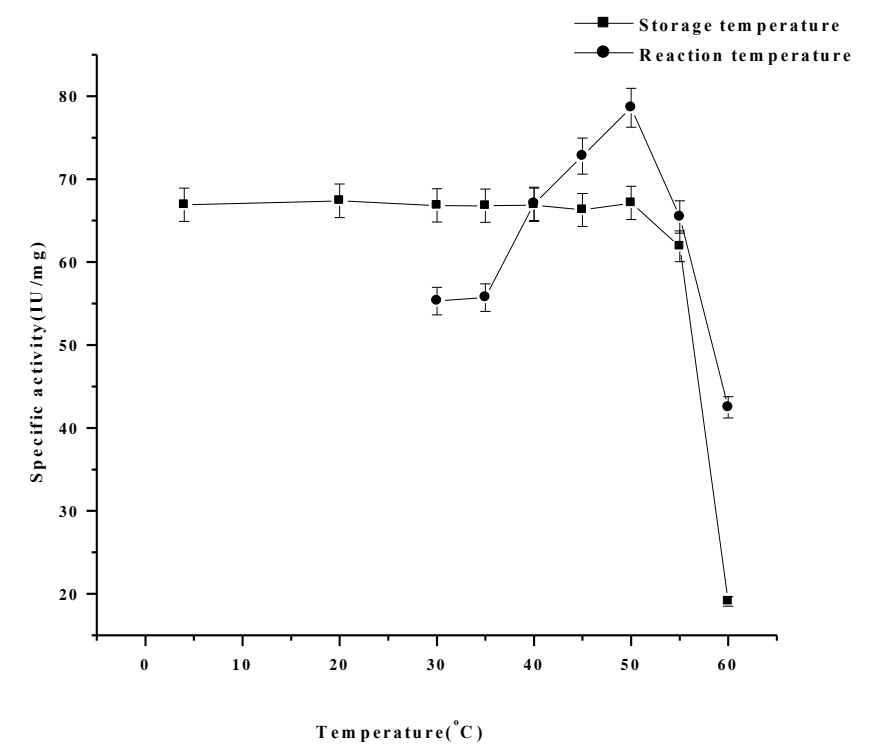

\section{Effect of temperature}

Activity of the purified enzyme was found to increase with increase in temperature, the optimum temperature upto $50^{\circ} \mathrm{C}$ and then it is decreased with increase in temperature
(Fig.5) and the enzyme also showed stability upto $50^{\circ} \mathrm{C} .94 .7 \%$ activity was retained even at $55^{\circ} \mathrm{C}$ after $1 \mathrm{~h}$ incubation. At higher temperatures, structure of the enzyme would tend to be distorted owing to thermal deactivation. The enzyme purified from the 
fungus Beauveria bassiana was optimally active at $50^{\circ} \mathrm{C}$, but not stable at $60^{\circ} \mathrm{C}$ (Macpherson et al., 1991).

\section{Effect of metal ions and reducing agents}

$\mathrm{Ca}^{2+}$ and $\mathrm{Co}^{2+}$ both at $0.5 \mathrm{mM}$, increased the activity of purified enzyme to 103.9 and $101.5 \%$, respectively. Sodium azide stimulated enzyme activity at all three concentrations. $\quad \beta$-mercaptoethanol and polyetheleneglycol, at $1.0 \mathrm{mM}, \mathrm{SDS}$ and CTAB at $5.0 \mathrm{mM}$ stimulated enzyme's activity (Table 4).

\section{Acknowledgements}

Authors gratefully thank Jadavpur University and Ministry of Food Processing Industries and Horticulture, Govt. of West Bengal, India for providing financial support to carry out the research work.

\section{References}

Bacterium: purification, characterization \& application for lactose hydrolysis. Appl. Microbiol. Biotechnol., Vol. 58(3): 313-321.

Bansal, S., Singh-Oberoi, H.S., SinghDhillon, G., Patil, R.T. 2008. Production of $\beta$-galactosidase by Kluyveromyces marxianus MTCC 1388 using whey and effect of four different methods of enzyme extraction on $\beta$-galactosidase activity . Indian J. Microbiol., Vol. 48(3): 337341.

Becerra, M., Rodríguez-Belmonte, E., Esperanza-Cerdán, I., Gonzalez-Siso, M.I.2001. Extraction of Intracellular Proteins from Kluyveromyces lactis. Food. Technol. Biotechnol., Vol. 39(2): 135-139.

Chakraborti, S., Sani, R.K., Banerjee, U.C., Sobti, R.C. 2003. Production \& Partial Characterization of a Novel $\beta$ - galactosidase from a newly isolated Bacillus polymyxa. Scientia Iranica., Vol.10 (3): 279-286.

Fernandes, S., Geueke, B., Delgado, O., Coleman, J., Hatti-Kaul, R. 2002. $\beta$ Galactosidase from a cold adapted

Fonseca, L.P., Cabral, J.M.S. 2002. Penicillin acylase release from Escherichia coli cells by mechanical cell disruption and permeabilization. $J$. Chem. Technol. Biotechnol., Vol. 77(2): 159-167.

Ganeva, V., Galutzov, B., Eynard, N., Teissie, J. 2001. Electroinduced extraction of $\beta$-galactosidase from Kluyveromyces lactis. J. Appl. Microbiol. Biotechnol., Vol. 56(34):411-413.

Georis, J., Esteves, F.L., Brasseur, J.L., Bougnet, V., Devreese, J.L.B., Frere, J.M. 2000.An additional aromatic interaction improves the thermostability and thermophilicity of a mesophilic family 11 xylanase: structural basis and molecular study. Protein Sc., Vol. 9(3): 466-475.

Ghatak, A., Roy, L., Guha, A.K. 2010. $\beta$-DGalactosidase from Enterobacter cloacae: Production \& Some Physicochemical Properties. Appl. Biochem. Biotechnol., Vol. 162(6): 1678-1688.

Gonzalez-Siso, M.I. 1996. The Biotechnological Utilization of Cheese Whey: A Review. Biores. Technol., Vol.5: 1-11.

Hsu, C.A., Yu, R.C. Chou, C.C. 2005. Production of $\beta$-galactosidase by Bifidobacteria as influenced by various culture conditions. Int. J. Food Microbiol., Vol.104(2): 197-206.

Husain, Q. 2010. $\beta$ Galactosidases and their potential applications: a review. Critical Rev. Biotechnol., Vol. 30(1): 41-62. 
Kula, M., Schutte, H. 1987. Purification of Proteins \& the disruption of Microbial cells. Biotechnol, Prog., Vol.3: 31-42.

Laemmli, U.K. 1970. Cleavages of Structural Proteins during the Assembly of the Head of Bacteriophage T4. Nature, Vol. 227(5259): 680-685.

Lowry, O.N., Rosebrough, N.J, Farr, A.L., Randall, R.J.1951. Protein measurement with the Folin phenol reagent. J. Biol. Chem., Vol.193(1): 265-275.

Macpherson, J.M., Khachatourians, G.G. 1991. Partial Purification and Characterization of $\beta$-Galactosidase Produced by Beauveria bassiana. Biotechnol. Appl. Biochem., Vol.13(2): 217-230.

Nagy, Z., Kiss, T., Szentirmai, A., Biro, S. 2001. $\beta$-Galactosidase of Penicillium chrysogenum:

Production, Purification and Characterization of the enzyme. Protein expression and purification., Vol. 21(1): 24-29.

Numanoglu, Y., Sungur, S. 2004. $\quad \beta$ Galactosidase from Kluyveromyces lactis cell disruption and enzyme immobilization using a cellulosegelatin carrier system. Process Biochem., Vol. 39: 703-709.

Onishi, N., Tanaka,T. 1995. Purification and properties of a novel thermostable galacto- oligosaccharide- producing $\beta$ galactosidase from Sterigmatomyces elviae CBS8119. Appl. Environ. Microbiol., Vol. 61(11):4026-4030.

Shukla, T.P. $1975 . \quad \beta$-Galactosidase Technology: A solution to Lactose problem, Crit. Rev. Food Sci. Nutria., Vol.5(3): 325-356.

\section{How to cite this article:}

Anamika Ghatak. 2016. $\beta$-Galactosidase from Enterobacter cloacae: Production, Characterization and Purification. Int.J.Curr.Microbiol.App.Sci. 5(7): 492-502. doi: http://dx.doi.org/10.20546/ijcmas.2016.507.054 